IBT Journal of Business Studies (IBT-JBS)

E-ISSN: 2409-6520; P-ISSN: 2414-8393

Volume 16:, 71-87 (2020)

DOI: 10.46745/ILMA.jbs.2020.161.01

\title{
Quality of Service as a Predictor of Customer Satisfaction in Healthcare Sector
}

\author{
Received: 21-Dec-2019 | Accepted: 25-7-2020
}

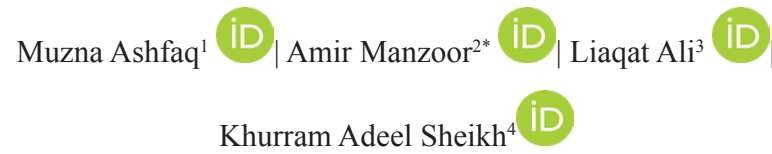

\begin{abstract}
This study examines role of quality of service as a predictor of customer satisfaction in private hospitals. Using a sample of customers of selected private hospitals in Karachi, this study used reliability statistics, Pearson correlation analysis, and OLS regression techniques to analyse the data. The results show that private hospitals are trying to deliver healthcare service that is at par with the expected standards set by their customers. The findings of this study will help management of these hospitals to develop and implement appropriate and effective strategies that would be helpful in delivering quality healthcare services to the patients. (6)
\end{abstract}

Keywords: Physical Environment, Communication, Privacy \& Safety, Responsiveness, Reliability, and Patient Satisfaction.

JEL Classification: $K 32, P 36, P 46, L 84$,

\section{Author's Affiliation:}

Institution:

Country:

Corresponding Author's Email:
Bahria University $1,2,3,4$

Pakistan

*amirmanzoor@yahoo.com

The material presented by the author(s) does not necessarily portray the view point of the editors and the management of the ILMA University, Pakistan. 2409-6520 (Online) 2414-8393 (Print) (C2020, published by the ILMA University, Pakistan.

This is open access article under the @- $@$ license. https://creativecommons.org/licenses/by/4.0/

Page $\mid 71$ 


\section{1) INTRODUCTION}

\section{1) BACKGROUND}

This study addresses the field of supply chain management and in particular one core aspect of it i.e. SQ. In today's era of global competition, supply chains no longer work in isolation, but channel coordination with every member of the chain (i.e. businesses, suppliers and customers). Satisfying every member of the supply chain is equally important if value is to be created. SQ plays an important role in developing close relationships since its association with improved supply chain performance is widely accepted (Aagja \& Garg, 2020).

\section{2) PROBLEM STATEMENT}

Increasing focus on health, global competition, rising population especially of senior citizens (and consequent health issues) have increased patient's concerns about the quality of healthcare services (Fatima, Malik, \& Shabbir, 2018; an efficient fabrication procedure to make nanoscale features on metallic films is required. We develop a simple and robust template-transfer approach to structure periodic nanohole arrays in optically thick Au films on poly(dimethylsiloxane Shabbir, 2016). In service industries, value creation and maintaining customer relationship requires provision of quality services. In developing nations, demands of patients and expectations are mostly neglected by hospital administrators and government policy makers (Javed \& Ilyas, 2018; Fatima et al., 2018)an efficient fabrication procedure to make nanoscale features on metallic films is required. We develop a simple and robust template-transfer approach to structure periodic nanohole arrays in optically thick Au films on poly(dimethylsiloxane. Moreover, despite the increasing emphasis on enhancing SQ in healthcare systems, the customer (patient) view) is still negligible (Shabbir, 2016). (3)

According to Ahmed, Tarique, and Arif (2017), there are health SQ issues, which warrant attention. Pakistan is one of the developing nations where provision of good healthcare SQ needs great attention (Javed \& Ilyas, 2018;Mustafa, 2006; S. S. Andaleeb, 2000; Shabbir et al., 2016). Studies that quantify the impact of SQ of customer outcomes are lacking. Hence, this study aims to bridge these gaps by investigating patient satisfaction within the context of private hospitals in Karachi, the largest metropolitan city of Pakistan.

\section{3) RESEARCH QUESTIONS}

This study aims to address the following research questions.

RQ1. How patient's satisfaction is influenced by various dimensions of the quality of healthcare service?

RQ2. Which parameters of quality of healthcare service are the most significant for increasing the level of patient's satisfaction? 


\section{4) RESEARCH OBJECTIVES}

Following are the objectives of this study:

To assess the relationship among various parameters of healthcare SQ and patient satisfaction.

To investigate healthcare services quality conditions provided by private hospitals of Pakistan and ascertain if any differences in quality exist

\section{2) LITERATURE REVIEW}

\section{1) SERVICE QUALITY}

Asubonteng, Mccleary, and Swan (1996) have described three underlying themes of SQ. Customer expectation is the foundation of his/her service evaluation (Asubonteng et al., 1996). The extent to which the service fulfils the needs of the customer determines how good the service will be regarded by the customers. According to Ramsaran-Fowdar (2009) (3), satisfied customers express themselves by showing preference for that company over others, praising the company, increasing their purchase in terms of volume and agreeing to pay a premium for the company's products.

\section{2) HEALTH CARE SERVICE QUALITY}

A returning customer of a hospital is the one who felt satisfied with quality of the service provided earlier to him/her earlier. Management of SQ encompasses both internal and external dimensions. The internal dimension places emphasis on zero defect and conformity to standards while perception, attitude, expectation and satisfaction are focused upon by the external dimension. In case of healthcare services, patients consider the interpersonal aspect to be of the highest importance (Swain \& Kar, 2018; Otani, Waterman, Faulkner, Boslaugh, \& Dunagan, 2010). Donabedian (1980) suggested that quality is more technical from the perspective of professionals and proposed three constructs: structure, process and outcome for its measurement. The most notable scale for measuring functional quality is SERVQUAL. This scale was developed by in a study conducted by Parasuraman et al., (1985) to asses SQ by comparing what customers expected and what was their perception (Jandavath \& Byram, 2016) (3). SERVQUAL includes five notable dimensions of SQ namely Tangibility, Reliability, Assurance, and Empathy). SQ in healthcare setting has also been measured extensively by using SERVQUAL and its modified versions (Swain \& Kar, 2018).

\subsection{1) PARAMETERS OF HEALTHCARE SERVICE QUALITY IN DEVELOPING NATIONS}

In developing countries, researchers have taken into account the cultural and contextual differences when attempting to assess the quality of healthcare service (Ramsaran-Fowdar, 2008). In India, the study done by Aagja \& Garg (2010)literature review of studies to measure service quality was undertaken. Later, Delphi method (two iterations developed a scale called PubHosQual aimed at assessing the quality Page $\mid 73$ 

of healthcare service offered by government healthcare providers.

\subsubsection{1.) PHYSICAL ENVIRONMENT}

Brady \& Cronin (2001) found that customers deemed service environment important in their assessment of quality. Within the context of healthcare, this dimension includes factors like medical equipment, physical facilities, staff appearance, infrastructure like well-planned waiting rooms ,bed layouts, cleanliness and is similar to SERVQUAL's dimension of "tangibles". Menu and related service is also a part of this dimension since food and supplementary services are important for in patients (Kondasani \& Panda, 2015) (3).

\subsubsection{2) CUSTOMER FRIENDLY ENVIRONMENT}

Customer friendly environment includes elements like customer care, staff's commitment to ensure a friendly environment, dealings based on empathy, kindness and superior quality of service available as per patient needs (Kondasani \& Panda, 2015) . This dimension relates to the "Empathy "and "Assurance" of Parasuraman's suggested model, measuring personnel's care, competence and ability to instigate trust and confidence of customers. In this respect, many studies such as Aliman and Mohamad (2013) (3), Amole et al., (2015), and Kondasani and Panda (2015) found empathy as a very important dimension of health care SQ as perceived by the patients.

\subsubsection{3) COMMUNICATION}

In the healthcare context, communication involves providing adequate information about treatments and medical tests, sharing timely information, counselling by staff, acknowledging patients, listening attentively and responding in the appropriate language and staff interactions (Kondasani \& Panda, 2015). A clear two way communication should enable the patient to express his problem and the doctor to understand the issue at hand (Kondasani \& Panda, 2015).

\subsubsection{4) PRIVACY AND SAFETY}

According to Kondasani \& Panda (2015), privacy and safety is the reduction or avoidance of actual or probable harm arising from healthcare. Importance of privacy has also been recognized in previous studies (Silvestro, 2005). Privacy also includes confidentiality during the treatment which is ranked as an important quality aspect by patient as established by (Mosadeghrad, 2013)in his study. Patient safety includes practices in place to reduce the likelihood of any adverse event with respect to exposure to medical treatment or any other condition within the hospital premises (Kondasani \& Panda, 2015).

\subsubsection{5) RESPONSIVENESS}

Responsiveness is the outcome which is the result of appropriately designed institutional relationships which adhere to customer expectations (Kondasani \& 
Panda, 2015). Responsive staff, which quickly attends to patient needs with courtesy and care, contributes to patient satisfaction (Syed Saad Andaleeb, 2001; Kazemi et al., 2013; Wathek, 2012; Aliman \& Mohamad, 2013; Syed Saad Andaleeb, 2001; Peprah \& Atarah, 2014; Butt \& de Run, 2010).

\subsubsection{6) RELIABILITY}

In healthcare SQ, reliability refers to the personnel's ability to provide patients the promised quality of medical care in a systematic manner. This dimension includes issues like, doctor availability, speed, and effectiveness of medicine, diagnosis, sufficient nursing time and proper diagnosis (Kondasani \& Panda, 2015; Naidu, 2009; Wathek, 2012). According to Ramsaran-Fowdar (2008) many studies on quality management have reported the reliability dimension as the most vital determinant of customers' perception of quality service.

\section{3) PATIENT SATISFACTION}

Patient satisfaction is in effect consumer satisfaction within the context of healthcare (Javed \& Ilyas, 2018; Neupane \& Devkota, 2017; Amin \& Nasharuddin, 2013). Patient satisfaction has been termed a multidimensional phenomenon with dimensions encompassing major features of both services and providers (Alhashem, Alquraini, \& Chowdhury, 2011) (3). Patients satisfaction level will be directly influenced by the amount of both technical and interpersonal benefits offered by healthcare service (Esch, Marian, Busato, \& Heusser, 2008)perception of side effects (higher percentage of reported side effects in the conventional group

\section{4) QUALITY OF HEALTHCARE SERVICE AND PATIENT SATISFACTION}

SQ is an antecedent of customer satisfaction. SQ has a strong relationship with the customer satisfaction (Cronin, Taylor, \& Taylor, 1992) (3). Chahal and Kumari (2010) found that patient satisfaction increases when the quality of healthcare service match or exceed patient's expectation. Many studies assessed the relationship between SQ and patient satisfaction in developing countries and found that increased patient satisfaction increased patient's inclination to trust the healthcare service provider, which would ultimately result in good reviews or positive word of mouth for the hospital (Peprah \& Atarah, 2014; Al-Borie et al., 2013 (3); Kazemi et al., 2013)the study analyzes relationship between HSQ and PS in the context of Iranian hospital services, using structural equation modeling (SEM.

\section{5) RESEARCH FRAMEWORK}

Figure 1 depicts the research framework of this study. The various parameters of quality of healthcare service that were examined in this study include physical environment, friendliness of environment, communication, privacy/safety, responsiveness, and reliability. 
Figure 1: Research Framework

Healthcare Service Quality

Physical Environment

Customer Friendly Environment

Communication

Privacy \& Safety

Responsiveness

Reliability

\section{6) HYPOTHESES}

Following are the hypotheses that have been developed based on the literature review:

H1- Patient satisfaction with quality of healthcare service is significantly impacted by physical environment.

$\mathrm{H} 2-$ Patient satisfaction with quality of healthcare service is significantly impacted by customer friendly environment.

H3- Patient satisfaction with quality of healthcare service is significantly impacted by communication.

H4- Patient satisfaction with quality of healthcare service is significantly impacted by privacy and safety offered by service.

H5- Patient satisfaction with quality of healthcare service is significantly impacted by responsiveness of the service.

H6- Patient satisfaction with quality of healthcare service is significantly impacted by reliability of the service.

\section{3) RESEARCH METHODOLOGY}

\section{1) NATURE OF RESEARCH}

This study has adopted an explanatory/ causal research approach to quantify relationship amongst various independent variables (Parameters of quality of healthcare service) and dependent variable (patient satisfaction).

\section{2) RESEARCH DESIGN}

The design of this study is quantitative and deductive. The study used primary data collected through a self-administered questionnaire. 


\section{3) TARGET POPULATION}

Total population considered for this study includes experienced patients of private hospitals in Pakistan. In accordance with the research question, this study has scaled down the scope towards private hospitals situated in Karachi. From all private healthcare institutions in Karachi, the names of six hospitals were included in the questionnaire, based on their size and reputation. Respondents were also invited to specify any other private hospital which they had visited most often.

\section{4) SAMPLE SIZE}

A sample size of 384 was selected which was deemed adequate in comparison to prior studies of similar nature (e.g. Badri, Attia, \& Ustadi, 2009 (3); there is one construct that represents patient's satisfaction with care (two variables - general and relative satisfactionAliman \& Mohamad, 2013; Ariffin, A. A. M., \& Aziz, 2008).

\section{5) DATA COLLECTION METHOD}

Aself-administered survey was used to collect data. The questionnaire was distributed both online and offline. The respondents were requested to fill questionnaire based on their experience of most frequently visited private hospitals.

\subsection{SAMPLING TECHNIQUE}

Non-probability convenience sampling technique was used for this study. This technique was deemed appropriate since the study's aim was only to investigate relationships amongst variables rather than to provide point and interval estimates (Aliman \& Mohamad, 2013)

\subsection{INSTRUMENT OF DATA COLLECTION}

This study adopted items from (Fatima et al., 2018)an efficient fabrication procedure to make nanoscale features on metallic films is required. We develop a simple and robust template-transfer approach to structure periodic nanohole arrays in optically thick Au films on poly(dimethylsiloxane and (Kondasani \& Panda, 2015). Total six independent variables were used in this research. A five point Likert scale was used to measure all items. The questionnaire used in this study consisted of two sections. Section "A" was based on demographics. Section "B" comprised of questions relating to six independent and one dependant variable of this study.

\subsection{STATISTICAL TECHNIQUES}

Reliability test, Pearson's correlation analysis, and OLS regression analysis were used. SPSS Version 22 was used to analyse the collected data. 


\section{4) DATA ANALYSIS}

\section{1) RESPONDENT PROFILE}

Table 1 exhibits the frequency and percentage of Age, Gender, Education, Monthly income and names of Private hospitals (visited most frequently).

Table 1: Respondents Demographic Information

\begin{tabular}{|c|c|c|c|}
\hline & & Frequency & Percentage \\
\hline \multirow[t]{5}{*}{ Age } & 19 to 24 & 107 & 27.9 \\
\hline & 25 to 35 & 208 & 54.2 \\
\hline & 36 to 45 & 48 & 12.5 \\
\hline & 46 to 55 & 15 & 3.9 \\
\hline & More than 55 years & 6 & 1.6 \\
\hline \multirow[t]{2}{*}{ Gender } & Female & 223 & 58.1 \\
\hline & Male & 161 & 41.9 \\
\hline \multirow[t]{6}{*}{ Education } & No formal education & 1 & 0.3 \\
\hline & Matriculation & 4 & 1.0 \\
\hline & Intermediate & 15 & 3.9 \\
\hline & Bachelors & 126 & 32.8 \\
\hline & Masters & 169 & 44 \\
\hline & Doctorate & 60 & 18 \\
\hline \multirow{5}{*}{$\begin{array}{l}\text { Monthly } \\
\text { income }\end{array}$} & Rs 15,000 or less & 83 & 21.6 \\
\hline & $\begin{array}{l}\text { Rs } 16,000 /- \text { to } \\
30,000 /-\end{array}$ & 41 & 10.7 \\
\hline & Rs $31,000 /-$ to 50,000 & 110 & 28.6 \\
\hline & $\begin{array}{l}\text { Rs } 50,000 /- \text { to } \\
100,000\end{array}$ & 91 & 23.7 \\
\hline & $\begin{array}{l}\text { More than Rs } \\
100,000 /-\end{array}$ & 59 & 15.4 \\
\hline \multirow{7}{*}{$\begin{array}{l}\text { Private } \\
\text { hospital } \\
\text { visited most } \\
\text { often }\end{array}$} & $\begin{array}{l}\text { Agha Khan } \\
\text { University Hospital }\end{array}$ & 167 & 43.5 \\
\hline & $\begin{array}{ll}\text { Liaquat } & \text { National } \\
\text { Hospital } & \end{array}$ & 80 & 20.8 \\
\hline & $\begin{array}{l}\text { Dr. Zia Uddin } \\
\text { Hospital }\end{array}$ & 41 & 10.7 \\
\hline & South City Hospital & 16 & 4.2 \\
\hline & $\begin{array}{l}\text { National Medical } \\
\text { Centre }\end{array}$ & 14 & 3.6 \\
\hline & Darul-Sehat Hospital & 34 & 8.9 \\
\hline & Others & 32 & 8.3 \\
\hline
\end{tabular}


IBT JOURNAL OF BUSINESS STUDIES (IBT-JBS) Volume 16 Issue 1, 2020

\section{2) RELIABILITY TEST STATISTICS (CRONBACH'S ALPHA)}

The values of reliability statistics for all the variables exceeded 0.7 (Saunders et al., 2003) (3). This shows that the internal consistency of all the variables was high. In other words, all the variables were reliable for further analyse

\section{3) CORRELATION}

Table 2: Pearson Correlation

\begin{tabular}{|c|c|c|c|c|c|c|c|c|}
\hline \multicolumn{9}{|c|}{ Correlations } \\
\hline & & $\mathrm{PH}$ & $\mathrm{CF}$ & COMM & PS & RES & RELI & PSAT \\
\hline \multirow[t]{3}{*}{$\mathrm{PH}$} & Pearson Correlation & 1 & $.733^{* *}$ & $.753^{* *}$ & $.738^{* *}$ & $.694^{* *}$ & $.701^{* \star}$ & $.706^{* *}$ \\
\hline & Sig. (2-tailed) & & .000 & .000 & .000 & .000 & .000 & .000 \\
\hline & $\mathrm{N}$ & 384 & 384 & 384 & 384 & 384 & 384 & 384 \\
\hline \multirow[t]{3}{*}{$\mathrm{CF}$} & Pearson Correlation & $.733^{* *}$ & 1 & $.763^{* *}$ & $.661^{* *}$ & $.795^{* *}$ & $.787^{\star \star}$ & $.771^{* \star}$ \\
\hline & Sig. (2-tailed) & .000 & & .000 & .000 & .000 & .000 & .000 \\
\hline & $\mathrm{N}$ & 384 & 384 & 384 & 384 & 384 & 384 & 384 \\
\hline \multirow[t]{3}{*}{ COMM } & Pearson Correlation & $.753^{* *}$ & $.763^{* *}$ & 1 & $.705^{* *}$ & $.740^{* *}$ & $.737^{\star \star}$ & $.776^{* *}$ \\
\hline & Sig. (2-tailed) & .000 & .000 & & .000 & .000 & .000 & .000 \\
\hline & $\mathrm{N}$ & 384 & 384 & 384 & 384 & 384 & 384 & 384 \\
\hline \multirow[t]{3}{*}{ PS } & Pearson Correlation & $.738^{* *}$ & $.661^{* \star}$ & $.705^{* *}$ & 1 & $.648^{* *}$ & $.665^{\star \star}$ & $.614^{* *}$ \\
\hline & Sig. (2-tailed) & .000 & .000 & .000 & & .000 & .000 & .000 \\
\hline & $\mathrm{N}$ & 384 & 384 & 384 & 384 & 384 & 384 & 384 \\
\hline \multirow[t]{3}{*}{ RES } & Pearson Correlation & $.694^{* *}$ & $.795^{* *}$ & $.740^{* *}$ & $648^{* *}$ & 1 & $.817^{* *}$ & $.735^{\star *}$ \\
\hline & Sig. (2-tailed) & .000 & .000 & .000 & .000 & & .000 & .000 \\
\hline & $\mathrm{N}$ & 384 & 384 & 384 & 384 & 384 & 384 & 384 \\
\hline \multirow[t]{3}{*}{ RELI } & Pearson Correlation & $.701^{* *}$ & $.787^{\star *}$ & $.737^{* *}$ & $.665^{* *}$ & $.817^{* *}$ & 1 & $.746^{* *}$ \\
\hline & Sig. (2-tailed) & .000 & .000 & .000 & .000 & .000 & & .000 \\
\hline & $\mathrm{N}$ & 384 & 384 & 384 & 384 & 384 & 384 & 384 \\
\hline \multirow[t]{3}{*}{ PSAT } & Pearson Correlation & $.706^{* *}$ & $.771^{* *}$ & $.776^{* \star}$ & $.614^{* *}$ & $.735^{* *}$ & $.746^{\star \star}$ & 1 \\
\hline & Sig. (2-tailed) & .000 & .000 & .000 & .000 & .000 & .000 & \\
\hline & $\mathrm{N}$ & 384 & 384 & 384 & 384 & 384 & 384 & 384 \\
\hline
\end{tabular}


IBT JOURNAL OF BUSINESS STUDIES (IBT-JBS) Volume 16 Issue 1, 2020 Table 3: Collinearity Diagnostics

\begin{tabular}{|l|l|}
\hline \multicolumn{1}{|c|}{ Tolerance } & \\
\hline & \\
\hline $.313(\mathrm{PH})$ & 3.192 \\
\hline $.262(\mathrm{CF})$ & 3.812 \\
\hline $.295(\mathrm{COMM})$ & 3.394 \\
\hline $.388(\mathrm{PS})$ & 2.578 \\
\hline .259 (RES) & 3.866 \\
\hline $.262(\mathrm{RELI})$ & 3.822 \\
\hline
\end{tabular}

Looking at Table 3 , we can see that the strongest significant correlation was between responsiveness and reliability $\left(\mathrm{r}=0.817^{* *}\right)$. The weakest significant correlation was between privacy/safety and responsiveness $\left(\mathrm{r}=0.648^{* *}\right)$. Looking at Table 4 , we see that VIF ( Variance inflation factor) of all variables was less than the threshold value of 10 ( $\mathrm{VIF}<10)$ (Duggirala et al., 2008) and all values of tolerance were found to be above 0.1 (Ismail \& Yunan, 2016) (3).

\section{4) REGRESSION ANALYSIS}

TABLE 4: MODEL SUMMARY

\begin{tabular}{|c|c|c|c|c|}
\hline \multicolumn{5}{|c|}{ Model Summary } \\
\hline Model & $\mathrm{R}$ & R Square & $\begin{array}{l}\text { Adjusted R } \\
\text { Square }\end{array}$ & $\begin{array}{c}\text { Std. Error of the } \\
\text { Estimate }\end{array}$ \\
\hline 1 & $.840^{a}$ & .705 & .700 & .54413 \\
\hline
\end{tabular}

a. Predictors: (Constant), RELI, PS, PH, COMM, CF, RES

The Table 4 shows that $\mathrm{R}$-square value of 0.705 . In social sciences, threshold for $\mathrm{R}$ square values lies at $0.6 \mathrm{t}$ in order to establish satisfaction with respect to the solution (Mustafa, 2006). Based on the aforementioned views, R-square for our model fits well. 
Table 5: ANOVA

ANOVA $^{\mathrm{a}}$

\begin{tabular}{|r|l|r|r|r|c|c|}
\hline \multicolumn{2}{|c|}{ Model } & \multicolumn{1}{c|}{$\begin{array}{c}\text { Sum of } \\
\text { Squares }\end{array}$} & \multicolumn{1}{c|}{ Df } & \multicolumn{1}{c|}{$\begin{array}{c}\text { Mean } \\
\text { Square }\end{array}$} & \multicolumn{1}{c|}{ F } & Sig. \\
\hline \multirow{3}{*}{1} & Regression & 267.416 & 6 & 44.569 & 150.531 & $.000^{\mathrm{b}}$ \\
& Residual & 111.918 & 378 & .296 & & \\
& Total & 379.334 & 384 & & & \\
\hline
\end{tabular}

a. Dependent Variable: PSAT

b. Predictors: (Constant), RELI, PS, PH, COMM, CF, RES

The Table 5 indicates a significance value, which is below the specified threshold of 0.05 . It suggests that the proposed model is overall significant.

Table 6: Coefficients

\begin{tabular}{|l|l|l|l|l|l|l|}
\hline \multirow{2}{*}{ Model } & \multicolumn{2}{|c|}{$\begin{array}{c}\text { Unstandardized } \\
\text { Coefficients }\end{array}$} & $\begin{array}{l}\text { Standardized } \\
\text { Coefficients }\end{array}$ & \multirow{2}{*}{$\mathrm{t}$} & Sig. \\
\cline { 2 - 6 } & \multicolumn{2}{|c|}{$\mathrm{B}$} & Std. Error & \multicolumn{2}{c|}{ Beta } & \\
\hline PH & .147 & .058 & .126 & 2.524 & .012 \\
CF & .284 & .063 & .244 & 4.479 & .000 \\
COMM & .334 & .052 & .328 & 6.382 & .000 \\
PS & -.063 & .050 & -.057 & -1.261 & .208 \\
RES & .112 & .062 & .100 & 1.826 & .069 \\
RELI & .219 & .067 & .179 & 3.282 & .001 \\
\hline
\end{tabular}

Looking at values of various coefficients, we see that results support hypothesis $\mathrm{H} 1, \mathrm{H} 2, \mathrm{H} 3$, and H6. The results do not provide evidence to support Hypotheses $\mathrm{H} 4$ and $\mathrm{H} 5$. 


\section{5) DISCUSSION}

This study hypothesized that various parameters of quality of healthcare service significantly impact the patient satisfaction. However, this study yielded some different results. Some parameters (such as physical environment, customer friendliness of environment, communication and reliability) were found to have significant impact on patient satisfaction but some paramours (such as responsiveness, privacy/safety and patient satisfaction) were found to have non-significant impact on patient satisfaction. The significant impact of physical environment is consistent with earlier studies conducted in the context of Bangladesh, India, and Malaysia [(Syed Saad Andaleeb, 2001), (Aliman \& Mohamad, 2013), (Nurafizah \& Annuar, 2018)]. Hence, this dimension holds immense value. A significant relationship between customer friendly environment and patient satisfaction is consistent with that of (Fatima et al., 2018),(Aliman \& Mohamad, 2013) and (Amole et al., 2015). A significant relationship between communication and patient satisfaction is consistent with findings of (ANDALEEB 2001) and (Kashkoli et al., 2017). A nonsignificant relationship between privacy and safety and patient satisfaction was contradictory to (Fatima et al., 2018) but in line with (Kondasani \& Panda, 2015). A non-significant relationship between responsiveness and patient satisfaction is in line with Nurafizah and Annuar (2018) and Javed and Ilyas, 2018). A significant relationship between reliability and patient satisfaction is in line with findings of previous studies conducted by (Aliman \& Mohamad, 2013), (Syed Saad Andaleeb, 2001),(Wathek, 2012) and (Javed \& Ilyas, 2018) .

\section{2) RESEARCH IMPLICATIONS}

This study identifies factors, which contribute the most towards satisfying patients of private hospitals. This study has provided valuable insights with respect to patient preferences from Karachi, the largest metropolitan city of Pakistan. Moreover, findings have once again reinstated that SQ is a significant antecedent of patient satisfaction. Findings from this research are valuable for healthcare service providers in Karachi. Managers of private hospitals should focus more on the interpersonal element of service provision if they want to ensure patient satisfaction. Interpersonal elements of services should be a focus area. Hospital management should make periodic investments in facilities and equipment to ensure tangible benefits of quality of healthcare services are sufficient.

\section{6) CONCLUSION AND RECOMMENDATIONS}

\section{1) CONCLUSION}

The prime focus of this study was the assessment of impact of various parameters of quality of healthcare service on patient satisfaction. It has identified the SQ condition of private hospitals in Karachi and the quality dimensions which profoundly increase satisfaction. Patients are more appreciative of the service provided by these hospitals, a finding that has been reported by various parts of the developing world including Egypt, Bangladesh, and India. Outcome of this study has provided valuable insights for private hospitals of Karachi. Findings highlight the 
importance of training for staff and practitioners to ensure adequate communication and a customer friendly environment, the two areas contributing the most towards patient satisfaction in this part of the country, as well as the significance of reliable services and maintaining an appealing physical environment.

\section{2) RECOMMENDATIONS}

Hospitals should conduct studies on a regular basis in order to evaluate patient satisfaction, since the latter have experienced services and are in a better position to provide valuable feedback, which can be used in decision-making. A Total Quality Management approach should be sought by management, which incorporates preferences and feedback of both patients and employees in designing the service delivery process. Private hospital management should periodically review their service design in order to address any problem areas that are newly found as well as to keep track of progress. This is important if hospitals are to provide value to their customers and remain competitive. Management and employees including staff, nurses and doctors should be cognizant of the value of quality service provision and patient satisfaction. Management should give the first priority to training of staff and practitioners for acquiring soft skills, since it is people which patients come across first when they visit the hospital, not medicine!. Technology and innovation should form an integral part of hospital's service provision. For instance, latest medical equipment and process innovation to enhance patient service experience can positively impact satisfaction. Management should plan and apply the quality dimensions in performing daily tasks of the hospital. This capability will significantly enhance positive patient outcomes i.e. satisfaction

Private hospitals should advocate communication openness between employees and patients through dissemination and sharing of SQ procedures and policies by using online platform and face-to-face interaction. This quality initiative approach can also be used for streamlining processes within the hospitals, for instance, reengineering procedures to enable fast and timely dissemination of information e.g. Quick access to health reports. Hospital employees inclusive of doctors and medical staff who exhibit a high level of commitment with quality service and are able to meet patient needs should be provided with extra monetary and nonmonetary rewards in order to motivate and retain them. Hospitals should stimulate a knowledge management strategy to encourage personnel to equip themselves with the latest skills, knowledge and abilities. Hospitals should motivate them towards application of what they have learned to enhance the delivery of service to patients.

\subsection{LIMITATIONS AND SUGGESTIONS FOR FUTURE RESEARCH}

This study was undertaken in Karachi only. Future studies may include other cities of Pakistan by applying this model to different hospitals with a larger sample size so that the findings of the study could be made more generalizable. This study used a quantitative approach to identify the SQ dimensions which were profoundly impacting satisfaction in private hospitals of Karachi. Future researchers may also consider may consider using qualitative approach along with the quantitative one to improve the findings. This study was focussed on private hospitals only. Future 
IBT JOURNAL OF BUSINESS STUDIES (IBT-JBS) Volume 16 Issue 1, 2020

researches may include both private and public hospitals to provide comparative studies.

\section{REFERENCES}

Aagja, J. P., \& Garg, R. (2010). Measuring perceived service quality for public hospitals (PubHosQual) in the Indian context. International Journal of Pharmaceutical and Healthcare Marketing, 4(1), 60-83. https://doi. org/10.1108/17506121011036033

Ahmed, S., Tarique, K.M. and Arif, I. (2017), "Service quality, patient satisfaction and loyalty in the

Bangladesh healthcare sector", International Journal of Health Care Quality Assurance, Vol. 30 No. 5.

Aliman, N.K. and Mohamad, W.N. (2013), "Perception of service quality and behavioral intentions: a mediation effect of patient satisfaction in private healthcare in Malaysia", International Journal of Marketing Studies, Vol. 5 No. 4, pp. 1918-7203.

Alrubaiee, L., \& Alkaa'ida, F. (2011). The Mediating Effect of Patient Satisfaction in the Patients' Perceptions of Healthcare Quality - Patient Trust Relationship. International Journal of Marketing Studies, 3(1), p103. https://doi.org/10.5539/ ijms.v3n1p103

Alhashem, A.M., Alquraini, H. and Chowdhury, R.I. (2011), "Factors influencing patient satisfaction in primary healthcare clinics in Kuwait", International Journal of Health Care Quality Assurance, Vol. 24 No. 3, pp. 249-262

Amin, M., \& Nasharuddin, S. Z. (2013). Hospital service quality and its effects on patient satisfaction and behavioural intention. Clinical Governance, 18(3), 238-254. https://doi.org/10.1108/CGIJ-05-2012-0016

Amole, B. B., Oyatoye, E. O., \& Adebiyi, S. O. (2015). Prioritization of service quality influences on patients' satisfaction using analytic hierarchy process: The Nigeria Experience. Izvestiya, Varna University of Economics. ИЗВЕСТИЯ, 60(1). (4)

Andaleeb, S. S. (2000). Public and private hospitals in Bangladesh: service quality and predictors of hospital choice. Health Policy and Planning, 15(1), 95-102. https://doi.org/10.1093/heapol/15.1.95

Andaleeb, S. S. (2001). Service quality perceptions and patient satisfaction: A study of hospitals in a developing country. Social Science and Medicine, 52(9), 1359-1370. https://doi.org/10.1016/S0277-9536(00)00235-5

Ariffin, A. A. M., \& Aziz, N. A. (2008). Determining the service quality dimensions 
IBT JOURNAL OF BUSINESS STUDIES (IBT-JBS) Volume 16 Issue 1, 2020

and zone of tolerance for hospital services in Malaysia. The Business Review, Cambridge, 10(2), 164-169. Retrieved from https://scholar.google.com.my/ scholar?hl=en\&as_sdt $=0,5 \&$ cluster $=14674043112331324067$

Asubonteng, P., McCleary, K.J. and Swan, J.E. (1996), "SERVQUAL revisited: a critical review of service quality", Journal of Services Marketing, Vol. 10 No. 6, pp. 62-81. (4)

Badri, M., Attia, S. and Ustadi, A.M. (2009), "Healthcare quality and moderators of patient satisfaction: testing for causality", International Journal of Health Care Quality Assurance, Vol. 22 No. 4, pp. 382-410.

Brady, M. K., \& Cronin, J. J. (2001). Some New Thoughts on Conceptualizing Perceived Service Quality: A Hierarchical Approach. Journal of Marketing, 65(3), 34-49. https://doi.org/10.1509/jmkg.65.3.34.18334

Butt, M. M., \& de Run, E. C. (2010). Private healthcare quality: Applying a SERVQUAL model. International Journal of Health Care Quality Assurance, 23(7), 658-673. https://doi.org/10.1108/09526861011071580

Chahal, H., \& Kumari, N. (2010). Development of multidimensional scale for healthcare service quality (HCSQ) in Indian context. Journal of Indian Business Research, 2(4), 230-255. https://doi.org/10.1108/17554191011084157

Donabedian, A. (1980). The definition of quality and approaches to its assessment. Health Administration Press. (4)

Duggirala, M., Rajendran, C., \& Anantharaman, R. N. (2008). Patient $\square$ perceived dimensions of total quality service in healthcare. Benchmarking: An International Journal, 15(5), 560-583. https://doi.org/10.1108/14635770810903150

Esch, B. M., Marian, F., Busato, A., \& Heusser, P. (2008). Patient satisfaction with primary care: An observational study comparing anthroposophic and conventional care. Health and Quality of Life Outcomes, 6(June). https://doi. org/10.1186/1477-7525-6-74

FATIMA, I., HUMAYUN, A., IQBAL, U., \& SHAFIQ, M. (2018). Dimensions of service quality in healthcare: a systematic review of literature. International Journal for Quality in Health Care, (June), 1-19. https://doi.org/10.1093/ intqhe/mzy125

Fatima, T., Malik, S. A., \& Shabbir, A. (2018). Hospital healthcare service quality, patient satisfaction and loyalty: An investigation in context of private healthcare systems. International Journal of Quality and Reliability Management, 35(6), 1195-1214. https://doi.org/10.1108/IJQRM-02-2017-0031

Ismail, A., \& Yunan, Y. M. (2016). Service quality as a predictor of customer satisfaction and customer loyalty. LogForum, 12(4), 269-283.

Page $\mid 85$ 
IBT JOURNAL OF BUSINESS STUDIES (IBT-JBS) Volume 16 Issue 1, 2020

Javed, S. A., \& Ilyas, F. (2018). Service quality and satisfaction in healthcare sector of Pakistan - the patients' expectations. International Journal of Health Care Quality Assurance, 31(6), 489-501. https://doi.org/10.1108/ IJHCQA-08-2016-0110

Kazemi, N., Ehsani, P., Abdi, F., \& Bighami, M. K. (2013). Measuring hospital service quality and its influence on patient satisfaction: An empirical study using structural equation modeling. Management Science Letters, 3(7), 21252136. https://doi.org/10.5267/j.msl.2013.06.005

Kashkoli, S. A., Zarei, E., Daneshkohan, A., \& Khodakarim, S. (2017). Hospital responsiveness and its effect on overall patient satisfaction. International journal of health care quality assurance.

Kondasani, R.K.R. and Panda, R.K. (2015), "Customer perceived service quality, satisfaction and loyalty in Indian private healthcare", International Journal of Health Care Quality Assurance, Vol. 28, No. 5, pp. 452-467.

Mosadeghrad, A. M. (2013). Healthcare service quality: Towards a broad definition. International Journal of Health Care Quality Assurance, 26(3), 203-219. https:// doi.org/10.1108/09526861311311409

Mustafa, M.M.(2006). An empirical study of patients 'expectations and satisfactions in Egyptian hospitals. https://doi.org/10.1108/09526860510627201

Naidu, A. (2009). Factors affecting patient satisfaction and healthcare quality. International Journal of Health Care Quality Assurance, 22(4), 366-381. https://doi.org/10.1108/09526860910964834

Nurafizah, S., \& Annuar, S. (2018). Determining The Effect of Service Quality Towards Patients' Satisfaction in Private Hospitals in Kota Kinabalu, Sabah Malaysia, 1-15.

Otani, K., Waterman, B., Faulkner, K. M., Boslaugh, S., \& Dunagan, C. W. (2010). How Patient Reactions to Hospital Care Attributes Affect the Evaluation of Overall Quality of Care, Willingness to Recommend, and Willingness to Return. Journal of Healthcare Management, 55(1), 25-38. https://doi. org/10.1097/00115514-201001000-00006

Parasuraman, A., Zeithaml, V. A., \& Berry, L. L. (1988). SERVQUAL: A MultipleItem Scale for Measuring Consumer Perceptions of Service Quality. Jorunal of Retailing, 64(1), 12-40. https://doi.org/10.1016/S0148-2963(99)00084-3

Peprah, A. A., \& Atarah, B. A. (2014). Assessing Patient's Satisfaction using SERVQUAL Model: A Case of Sunyani Regional Hospital, Ghana. International Journal of Business and Social Research, 4(2), 133-143. https:// doi.org/10.1108/09526861011071580 
IBT JOURNAL OF BUSINESS STUDIES (IBT-JBS) Volume 16 Issue 1, 2020

Ramsaran-Fowdar, R.R. (2009), "A study of service quality of stockbrokers in Mauritius using a multiexpectations approach", International Conference of Business and Information, Vol. 13 No. 4, pp. 1-12

Saunders, M., Lewis, P., \& Thornhill, A. (2003). Research methods forbusiness students. Essex: Prentice Hall: Financial Times.

Silvestro, R. (2005). Applying gap analysis in the health service to inform the service improvement agenda. International Journal of Quality \& Reliability Management, 22(3), 215-233. https://doi.org/10.1108/02656710510582462

Swain, S., \& Kar, N. C. (2018). Hospital service quality as antecedent of patient satisfaction - a conceptual framework. International Journal of Pharmaceutical and Healthcare Marketing, 12(3), 251-269. https://doi.org/10.1108/ IJPHM-06-2016-0028

Wathek, R. (2012). Patients' Perception of Health Care Quality, Satisfaction and Behavioral Intention : An Empirical Study in Bahrain. International Journal of Business and Social Science, 3(18), 131-141. 